\title{
UJI EFEKTIVITAS SALEP EKSTRAK TERIPANG PASIR (HOLOTHURIA SCABRA) SEBAGAI ANTIINFLAMASI DENGAN METODE UDEM PADA KAKI TIKUS YANG DIINDUKSI KARAGENAN
}

\author{
${ }^{1}$ Ahmad Azrul Zuniarto \\ ${ }^{2}$ Anna Pradiningsih \\ ${ }^{3}$ Ais Hamidah \\ ${ }^{1}$ Prodi S1 Farmasi Sekolah Tinggi Farmasi YPIB Cirebon annapradiningsih@gmail.com \\ 2 Prodi S1 Farmasi Sekolah Tinggi Farmasi YPIB Cirebon aazuniarto@gmail.com \\ ${ }^{3}$ Prodi S1 Farmasi Sekolah Tinggi Farmasi YPIB Cirebon iezdee17@gmail.com
}

\begin{abstract}
ABSTRAK
Teripang pasir (Holothuria scabra) merupakan biota laut yang banyak ditemukan di perairan Indonesia, Namun, oleh masyarakat Holothuria scabra belum dimanfaatkan secara optimal baik sebagai bahan pangan berkhasiat medis maupun sebagai komoditas yang bernilai ekonomis. Tujuan dari penelitian ini adalah untuk mengetahui efektivitas salep ekstrak teripang pasir sebagai antiinflamasi dengan metode udem pada kaki tikus yang diinduksi karagenan dan untuk mengetahui konsentrasi salep ekstrak teripang pasir yang efektif sebagai antiinflamasi dengan metode udem pada kaki tikus yang diinduksi karagenan

Metode yang digunakan dalam penelitian ini adalah metode udem telapak kaki tikus yang diinduksi karagenan. Efektivitas antiinflamasi salep ekstrak teripang pasir (Holothuria scabra) dibandingkan dengan thrombophob salep dikarenakan thrombophob memiliki potensi dalam penurunan udem. Penelitian dilakukan dengan tiga kali pengulangan pada masing - masing kelompok yang diberi perlakuan. Penurunan volume telapak kaki tikus diukur sebelum diberi perlakuan, setelah diinduksi karagenan dan setelah diberi perlakuan setiap jam berturut - turut selama kurun waktu 6 jam.

Hasil penelitian uji efektivitas antiinflamasi menunjukkan bahwa salep ekstrak teripang pasir (Holothuria scabra) memiliki efek antiinflamasi yang ditunjukkan dalam uji anava satu jalur dengan nilai signifikan $0,000<0,005$. Untuk mengetahui konsentrasi paling efektif data diuji dengan uji $\mathrm{T}$ pada salep ekstrak teripang pasir konsentrasi $60 \%$ tidak berbeda secara signifikan dengan thrombophob salep dengan nilai signifikan 0,914>0,005 sedangkan salep ekstrak teripang konsentrasi $15 \%$ memiliki perbedaan dengan nilai signifikan 0,001<0,005 dan Salep ekstrak teripang konsenstrasi 30\% memiliki nilai signifikan $0,004<0,005$. Daya antiinflamasi salep ekstrak teripang pasir konsentrasi $60 \%$ memiliki nilai yang hampir sama dengan kontrol positif yakni $13,15 \%$ dimana kontrol positif memiliki daya antiinflamasi $11,83 \%$. Sedangkan salep ekstrak teripang pasir konsentrasi $15 \%$ dan 30\% memiliki daya antiinflamasi 31,04\% dan 24,34\%. Hal ini dikarenakan salep dengan konsnentrasi $60 \%$ memiliki molekul yang lebih besar dibandingkan salep dengan konsentrasi $15 \%$ dan 30\% sehingga lebih sulit menembus dinding semi permeabel sel dan menghambat penurunan udem.
\end{abstract}


Kata kunci : Antiinflamasi, Salep ekstrak teripang pasir, Udem, Karagenan.

\begin{abstract}
Sea cucumber (Holothuria scabra) is a marine biota that is commonly found in Indonesian waters, however, by the society of Holothuria scabra has not been optimally utilized either as a food nutritious medical or as a commodity of economic value. The purpose of this research is to know the effectiveness of the sea cucumber ointment extract as anti-inflammatory with udem rat feet method, to know the concentration of ointment extract of sand sea cucumber which is effective as anti-inflammatory with udem method induced carrageenan and to know salve of sea cucumber extract Sand made to meet the standards of evaluation of ointment preparations and drug stability tests.

The method used in this research is udem method of rat foot induced carrageenan. The effectiveness of antiinflammatory ointment of sand cucumber extract (Holothuria scabra) compared with thrombophob ointment due to thrombophob has the potential in decreasing udem. The study was conducted with three repetitions in each treated group. The decrease in rat foot volume was measured before treatment, after induction of carrageenan and after being treated every hour consecutively for a period of 6 hours.

The results of the anti-inflammatory efficacy test showed that the salt extract of the sea cucumber (Holothuria scabra) had anti-inflammatory effect shown in the one-track anava test with significant value $0.000<0,005$. To find out the most effective concentration of data tested with $\mathrm{T}$ test on ointment extract of sea cucumber concentration $60 \%$ not significantly different with thrombophob ointment with significant value $0,914>0,005$ while salt extract sea cucumber $15 \%$ concentration have difference with significant value $0,001<0,005$ and Salak extract sea cucumber A $30 \%$ concentration has a significant value of $0.004<0.005$. Anti-inflammatory ointment extract of sea cucumber extract $60 \%$ of sand has almost the same value with positive control that is $13.15 \%$ where the positive control has anti inflammatory power of $11.83 \%$. While salt extract sea cucumber concentration of $15 \%$ and $30 \%$ have anti-inflammatory power $31.04 \%$ and $24.34 \%$. This is because an ointment with $60 \%$ concentration has a larger molecule than an ointment with concentrations of $15 \%$ and $30 \%$ making it more difficult to penetrate the semi permeable wall of the cell and inhibit the decrease in udem
\end{abstract}

Keywords : Anti-inflammatory, sea cucumber, udem, carrageen induced.

\title{
1. PENDAhuluan
}

Teripang atau timun laut merupakan salah satu fauna laut yang hidup didaerah lautan dangkal terutama banyak terdapat diperairan laut jawa. Teripang masuk dalam anggota hewan berkulit duri (Echinodermata). Namun, tidak semua jenis teripang mempunyai duri pada kulitnya. Ada beberapa jenis teripang yang tidak berduri. Diantara empat famili teripang, hanya famili Holothuriidae yang dapat dimakan dan bernilai ekonomis (Darsono, 2007). 
PharmaXplore

Jurnal Sains dan Ilmu Farmasi
ISSN: 2527-5801

Vol. 2 No 3 Mei 2017

Teripang merupakan komoditas perikanan yang bernilai ekonomis tinggi dan umumnya diperdagangkan dalam bentuk kering. Teripang umumnya dikonsumsi dalam bentuk olahan, seperti gonad kering (konoko), usus kering (konowata) atau kerupuk. Teripang mengandung zat-zat aktif yang bermanfaat dalam bidang farmasi dan kesehatan. (Kustiariyah, 2007).

Pada beberapa penelitian diketahui bahwa teripang mengandung flavonoid (Memelona et al.dalam Indra, 2012). Beberapa golongan flavonoid telah dibuktikan memiliki efek antiradang dengan menghambat enzim siklooksigenase atau lipoksigenase yang dapat mengkatalis metabolisme asam 6 arakhidonat. Flavonoid dalam bentuk glikosida memiliki sifat polar sehingga dapat larut dalam pelarut air dan alkohol.

Berdasarkan penelitian Efek penyembuhan luka bakar menggunakan hewan uji kelinci yang mengalami luka bakar diameter $1,5 \mathrm{~cm}$. menunjukkan bahwa Ekstrak methanol teripang konsentrasi $30 \%$ dalam sediaan gel memeiliki prosentase penyembuhan luka $74.4 \%$ pada hari ke tujuh, sedangkan bioplacenton, kontrol positif, memiliki prosentase penyembuhan luka 89,4\%.

Kondisi cedera, pasca operasi dan kecelakaan merupakan keadaan yang tidak dapat dihindari sehingga rasa sakit akibat peradangan (inflamasi) sering kali terjadi secara tiba - tiba pada manusia. Menurut Mutschler dan Korolkovas dalam Djumain (2014) inflamasi merupakan mekanisme pertahanan tubuh disebabkan adanya respons jaringan terhadap pengaruh-pengaruh merusak, baik bersifat lokal maupun yang masuk ke dalam tubuh. Pengaruh-pengaruh merusak ( noksi ) dapat berupa noksi fisika, kimia, bakteri, parasit, asam, basa kuat dan bakteri. Sedangkan menurut Bagian Farmakologi FKUI dalam Wahjo Dyatmiko dkk (2003) Bengkak atau inflamasi merupakan rangkaian perubahan yang kompleks dalam jaringan akibat cedera jaringan, baik yang disebabkan oleh bakteri, trauma, zat kimia, panas atau setiap fenomena lainnya. Respon inflamasi ditandai dengan adanya warna merah karena adanya aliran darah yang berlebihan pada daerah injuri, panas yang merupakan respon inflamatoris pada permukaan tuhuh, bengkak karena pengiriman cairan dan sel-sel dari sirkulasi darah ke daerah interstisial, rasa nyeri karena adanya perubahan $\mathrm{pH}$ lokal atau konsentrasi lokal ion-ion tertentu dan gangguan fungsi belum diketahui secara mendalam dengan jalan bagaimana fungsi jaringan yang meradang terganggu. Berdasarkan data yang diterbitkan Cheri dalam Djumain (2014) Penyakit inflamasi banyak dijumpai di Rumah sakit umum, rumah sakit anak dan rumah sakit gigi, sehingga 
pemakain obat obat anti inflamasi dari hari kehari terus meningkat dengan atau tanpa resep dokter.

\section{METODE PENELITIAN}

\section{Determinasi Teripang}

Hewan dideterminasi dengan menggunakan buku kunci determiniasi, hal ini bertujuan untuk mengetahui apakah hewan yang diteliti adalah benar merupakan teripang. Identifikasi dan pengenalan kelompok dan jenis hewan merupakan bagian yang sangat penting dalam taksonomi. Salah satu alat bantu identifikasi adalah kunci Determinasi yang dipakai untuk menentukan kedudukan hewan dalam sistematika hayati. Ada kunci untuk menentukan Filum (Phylum), Kelas (Class), Bangsa (Ordo), Suku (Family), Marga (Genus) dan Jenis (Species) hewan (Saanin, 1986). Kunci determinasi atau kunci dikotom adalah cara atau langkah untuk mengenali organisme dan mengelompokkannya pada takson makhluk hidup. Kunci dikotomis terdiri dari sederetan pernyataan yang terdiri dari dua baris dengan ciri yang berlawanan. Kunci determinasi pertama kali diperkenalkan oleh Carolus Linnaeus, tetapi sebenarnya Lammarck (1778) yang pernah menggunakan kunci modern untuk identifikasi.

\section{Pengambilan dan Pengolahan Sampel/ Bahan}

Sampel yang berupa teripang pasir diperoleh di Pasar Eretan kabupaten Indramayu Provinsi Jawa Barat. Sampel yang diperoleh dibersihkan dari kotoran kemudian digosok dengan enzim papain, setelah itu dipisahkan dari jeroannya dengan cara membelah secara melintang kemudian mengeluarkan jeroannya, atau dengan menusuk salah satu ujung anusnya dengan kayu kemudian diputar supaya ususnya lepas. Bagian yang satu ditekan supaya isi ususnya keluar.

\section{Pembuatan Simplisia}

Teripang yang sudah dipisahkan dari jeroannya, dagingnya dipotong-potong kecil kemudian dikeringkan dalam oven dengan suhu $50^{\circ} \mathrm{C}$ selama beberapa hari sampai kering kemudian diblender hingga menghasilkan serbuk. Selanjutnya siap untuk diekstraksi secara maserasi.

\section{Pembuatan Ekstrak Teripang}


Sampel kering dari teripang pasir ditimbang sebanyak 150 gram dimasukkan kedalam bejana maserasi lalu ditambahkan larutan penyari etanol 96\%. Perbandingan sampel dengan pelarut penyari adalah 10 bagian dalam 70 bagian pelarut atau sampai semua sampel terendam. Bejana maserasi kemudian ditutup rapat dan dibiarkan selama 5 hari sambil diaduk dan disimpan pada tempat yang tidak terkena sinar matahari. Setelah 5 hari diserkai, ampas diperas. Pada ampas ditambah cairan penyari secukupnya, diaduk dan diserkai sehingga diperoleh seluruh sari sebanyak 100 bagian. Bejana ditutup dan dibiarkan ditempat sejuk, terlindung dari cahaya, selama 2 hari kemudian endapan dipisahkan. Ekstrak yang diperoleh kemudian dikumpulkan dan dipekatkan dengan menguapkannya pada penangas uap hingga tersisa $1 / 3$ bagian penguapan dilanjutkan sampai diperoleh ekstrak kental.

\section{Perhitungan Presentase daya Antiinflamasi}

Data yang dikumpulkan berupa volume udem sebelum dan selama perlakuan berlangsung, untuk menghitung persentase kenaikan volume udem tiap waktu digunakan Persamaan Sebagai berikut : (Hanifah, 2015).

$\%$ Kenaikan Volume Udem $(\mathrm{KVU})=\frac{V_{t}-V_{0}}{V_{0}} \times 100 \%$

Keterangan :

$\mathrm{Vt}=$ volume telapak kaki tikus pada waktu tertentu,

$\mathrm{V} 0=$ volume telapak kaki tikus sebelum pemberian obat.

Setelah menghitung persentase kenaikan volume udem kemudian dihitung harga Area Under Curve (AUC) yang nantinya digunakan untuk menghitung nilai persentase daya anti inflamasi (DAI) dalam bentuk persentase. Adapun Persamaannya adalah sebagai berikut :

$\%$ Daya Antiinflamasi $=\frac{A U C_{k}-A U C_{P}}{A U C_{P}} \times 100 \%$

Keterangan :

$A U C_{k}=$ Area Under Curve total Kontrol untuk Negatif

$A U C_{p}=$ Area Under Curve total Kelompok Perlakuan

Sedangkan Presentase inhibisi radang dinyatakan dalam persamaan sebagai berikut :

$\%$ inhibisi radang $=\frac{\% \text { radang kontrol }-\% \text { radang } u j i}{\% \text { radang kontrol }} \times 100 \%$

\section{Formulasi Salep Ekstrak Teripang pasir}

Salep Ekstrak Teripang pasir Kadar 15\% , 30\%, 60\%

R/ Ekstrak Teripang pasir 15\% 
Nipagin $\quad 0,1 \%$

Vaselin album sampai 50gr

M.F. Ungt

\begin{tabular}{lccc} 
& \multicolumn{4}{c}{ Tabel 3.1 Formulasi Salep Ekstrak Teripang } \\
\hline \multicolumn{1}{c}{ Formulasi } & $\mathrm{A}$ & $\mathrm{B}$ & $\mathrm{C}$ \\
\hline Ekstrak Teripang pasir & $7,5 \mathrm{gr}$ & $15 \mathrm{gr}$ & $30 \mathrm{gr}$ \\
Nipagin & $0,05 \mathrm{gr}$ & $0,05 \mathrm{gr}$ & $0,05 \mathrm{gr}$ \\
Vaselin album & $42,45 \mathrm{gr}$ & $34,95 \mathrm{gr}$ & $19,95 \mathrm{gr}$ \\
\hline
\end{tabular}

\section{Teknik Pembuatan Salep Ekstrak Teripang}

Menyiapkan bahan dan alat. Menimbang ekstrak teripang, nipagin dan vaselin album . Memanaskan lumpang dan mortir agar dasar salep tercampur homogen dengan bahan uji. Masukkan nipagin dan sebagian kecil vaselin untuk melapisi mortir tambahkan ekstrak kental sedikit demi sedikit gerus hingga homogeny. Masukkan sisa vaselin gerus hingga homogen. Mengemas salep dalam pot salep dan memberi tanda pada masing - masing konsentrasi.

\section{Uji Antiinflamasi pada Hewan Percobaan}

Hewan percobaan yang digunakan dalam penelitian ini adalah Tikus Putih (Rattus noovergicus) sehat, dan dewasa dengan berat 200 gram. Sebelum diberi perlakuan tikus diadaptasi selama satu minggu. Langkah kerja perlakuan adalah menyiapkan tikus sebanyak 15 ekor. Membagi 15 ekor hewan uji menjadi 5 kelompok (masing - masing 3 ekor tikus dengan ketentuan 3 ekor Tikus untuk kelompok kontrol positif, 3 ekor Tikus untuk Kontrol Negatif, 3 ekor Tikus untuk uji antiinflamasi dengan salep ekstrak teripang 15\%, 3 ekor Tikus untuk uji antiinflamasi dengan salep ekstrak teripang $30 \%$ dan 3 ekor Tikus untuk uji antiinflamasi dengan salep ekstrak teripang $60 \%$. Tandai masing - masing tikus sesuai dengan kelompok yang akan diujikan. Suntikkan kaki Tikus dengan karagenan $1 \%$, ukur diameter $\pm 3-5 \mathrm{~cm}$. Mengukur volume kaki tikus setelah diinduksi karagenan. Memberikan perlakuan pada Tikus yang telah diinduksi karagenan dengan ketentuan sebagai berikut :

Kelompok I : Mengoleskan Basis Salep pada Kaki Tikus ( Kontrol Negatif)

Kelompok II : Mengoleskan salep Thrombophob pada Kaki Tikus (Kontrol Positif)

Kelompok III : Mengoleskan salep ekstrak teripang konsentrasi 15\% pada Kaki Tikus.

Kelompok IV : Mengoleskan salep ekstrak teripang konsentrasi 30\% pada Kaki Tikus. 
Kelompok V : Mengoleskan salep ekstrak teripang konsentrasi $60 \%$ pada Kaki Tikus.

Mengukur volume telapak kaki tikus pada jam ke 1, 2, 3, 4, 5 dan 6 dengan menggunakan Plestimometer. Mengamati reaksi yang terjadi dan mencatat perubahan yang terjadi pada masing - masing kelompok.

\section{PEMBAHASAN}

\section{Hasil Determinasi}

Determinasi Teripang Pasir bertujuan untuk memastikan kebenaran sampel Hewan yang akan digunakan sebagai bahan uji dalam penelitian. Determinasi Teripang Pasir dilakukan dengan cara mencocokan cirri morfologi yang ada pada Teripang pasir terhadap beberapa kepustakaan yang dilakukan di laboratorium zoology avertebrata Sekolah Tinggi Keguruan dan Ilmu Pengetahuan Pangeran dharma Kusuma Indramayu. Hasil Determinasi menyatakan bahwa Sampel adalah Teripang Pasir (Holothuria scabra).

\section{Hasil Pembuatan Salep Ekstrak Teripang Pasir}

Rendemen merupakan persentase bagian bahan baku yang dapat digunakan atau dimanfaatkan dengan total bahan baku. Semakin tinggi nilai rendemen menandakan bahwa bahan baku tersebut memiliki peluang untuk dimanfaatkan lebih besar. Rendemen merupakan persentase sampel sebelum dan setelah perlakuan.

Adapun perhitungan rendemen ekstrak teripang pasir sebagai berikut :

$$
\begin{aligned}
\text { Rendemen } & =\frac{\text { BeratEkstrakKentalTotal }}{\text { BeratSimplisia }} \times 100 \% \\
\text { Rendemen } & =\frac{62,5}{150} \times 100 \% \\
& =41,6 \%
\end{aligned}
$$

Berdasarkan perhitungan rendemen didapatkan hasil 41,6\% Hal ini menunjukkan kandungan senyawa metabolit sekunder yang ada pada ekstrak teripang pasir cukup banyak. Selebihnya merupakan kandungan air dan serat. Semakin lama waktu ekstrak dan semakin halus ekstraknya, maka semakin banyak pula rendemen yang didapatkan. Semakin besar perbandingan bahan baku-pelarut yang digunakan, maka semakin banyak ekstrak kasar yang didapat. Untuk mendapatkan ekstrak yang lebih banyak harus dilakukan ekstraksi yang lebih lama.

\section{Hasil Uji Antiinflamasi}


Uji efektivitas antiinflamasi pada tikus jantan menggunakan jangka sorong dilakukan tiap 1 jam dalam kurun waktu 6 jam. Hasil data yang diperoleh berupa kenaikan volume udem telapak kaki tikus setelah diinduksi karagenan dan penurunan volume udem telapak kaki tikus setelah diberikan salep ekstrak teripang pasir dan kontrol positif. Adapun data hasil pengukuran volume udem telapak kaki tikus dapat dilihat pada tabel berikut :

Tabel 4.1 Tabel data Uji antiinflamasi

\begin{tabular}{|c|c|c|c|c|c|c|c|c|c|c|}
\hline \multirow{2}{*}{ Kelompok } & \multirow{2}{*}{ Vo } & \multirow{2}{*}{$\begin{array}{l}\text { setelah } \\
\text { induksi }\end{array}$} & \multicolumn{6}{|c|}{ Volume telapak kaki tikus pada jam ke - } & \multirow{2}{*}{$\%$ DAI } & \multirow{2}{*}{$\begin{array}{c}\% \text { Inhibis } \\
\text { Radang }\end{array}$} \\
\hline & & & 1 & 2 & 3 & 4 & 5 & 6 & & \\
\hline $\mathrm{X} 1$ & 0,52 & 1,07 & 0,97 & 0,92 & 0,81 & 0,71 & 0,66 & 0,60 & 31,04 & 64,30 \\
\hline $\mathrm{X} 2$ & 0,48 & 1,22 & 1,09 & 1,04 & 0,93 & 0,80 & 0,69 & 0,61 & 24,34 & 45,50 \\
\hline $\mathrm{X} 3$ & 0,47 & 1,22 & 1,18 & 1,13 & 1,02 & 0,94 & 0,86 & 0,78 & 13,15 & 20,10 \\
\hline $\mathrm{K}+$ & 0,60 & 1,33 & 1,25 & 1,18 & 1,05 & 0,94 & 0,83 & 0,74 & 11,83 & 54,60 \\
\hline $\mathrm{k}-$ & 0,49 & 1,30 & 1,27 & 1,25 & 1,20 & 1,12 & 1,02 & 0,94 & 0,00 & 0,00 \\
\hline
\end{tabular}

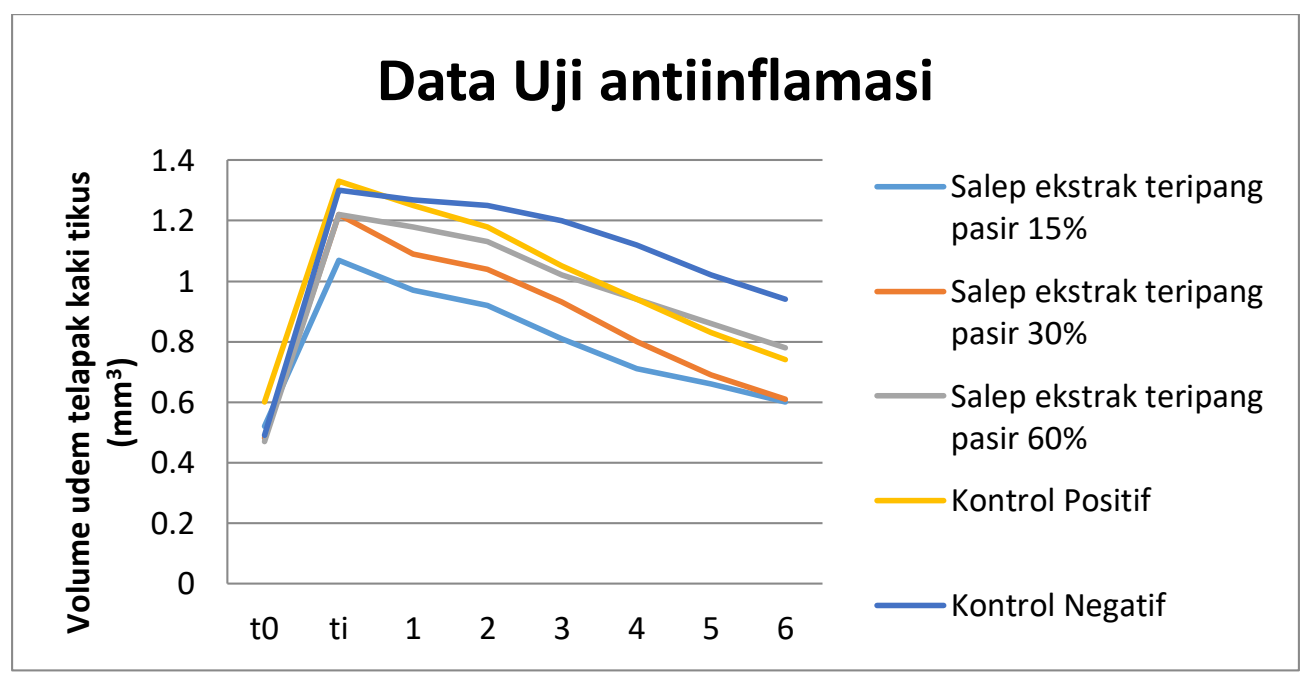

Gambar. 4.6 Grafik perbandingan penurunan udem telapak kaki tikus pada masing - masing kelompok

\section{Analisa Data}

Berdasarkan perhitungan anava satu jalur menggunakan spss 18 didapatkan nilai $\mathrm{F}$ hitung sebesar 11,331 dengan nilai signifikasi 0,000 karena nilai sig. 0,000 lebih kecil dari 0,005, maka Ho ditolak dan H1 diterima. Begitupula Dengan demikian dapat disimpulkan bahwa terdapat efektivitas perbedaan yang signifikan antara kontrol positif dengan salep ekstrak teripang pasir 15\%, 30\% dan 60\%. ( Riadi, Edi : 262). Adapun f tabel adalah 2,48.

Berdasarkan hasil uji t test salep ekstrak teripang pasir $15 \%$ dengan kontrol positif diperoleh data thitung sebesar 3,516 sedangkan $\mathrm{t}$ tabel untuk $\mathrm{df}=34$ adalah 1,697. Berdasarkan hasil uji t test salep ekstrak teripang pasir 30\% dengan kontrol positif diperoleh data t hitung 
PharmaXplore

Jurnal Sains dan Ilmu Farmasi
ISSN: 2527-5801

Vol. 2 No 3 Mei 2017

sebesar 2,115 sedangkan $\mathrm{t}$ tabel untuk $\mathrm{df}=34$ adalah 1,697. Maka karena t hitung lebih besar dari $\mathrm{t}$ tabel dapat disimpulkan bahwa terdapat perbedaan signifikan dari rata - rata jumlah volume udem telapak kaki tikus yang diberi perlakuan dengan salep ekstrak teripang konsentrasi 15\% dan 30\% dengan kelompok kontrol positif, dalam hal ini salep ekstrak teripang konsentrasi 15\% dan 30\% memiliki daya antiinflamasi lebih baik dikarenakan adanya kandungan saponin glikosida serta cell growth factor yang mampu meregenerasi sel sehingga penurunan udem lebih cepat sedangkan pada kontrol positif zat aktif yang digunakan adalah heparin yang lebih terkonsentrasi pada pencegahan pembekuan darah.

Berdasarkan hasil uji t test salep ekstrak teripang pasir $60 \%$ dengan kontrol positif diperoleh data $t$ hitung sebesar 0,109 sedangkan $t$ tabel untuk $\mathrm{df}=34$ adalah 1,697. Maka karena $\mathrm{t}$ hitung lebih kecil dari t tabel dapat disimpulkan bahwa rata - rata jumlah volume udem telapak kaki tikus yang diberi perlakuan dengan salep ekstrak teripang konsentrasi 60\% dengan kelompok kontrol positif hampir memiliki nilai yang sama.

\section{PENUTUP}

\section{Kesimpulan}

1. Salep ektrak teripang pasir ( Holothuria scabra) memiliki efektifitas antiinflamasi dengan metode udem pada kaki tikus yang diinduksi karagenan.

2. Salep ekstrak teripang pasir ( Holothuria scabra ) mempunyai efek antiinflmasi dengan metode udem pada kaki tikus yang diinduksi karagenan dengan konsentrasi 15\%, 30\% dan $60 \%$ namun secara signifikan salep ekstrak teripang pasir konsentrasi 15\% dan 30\% lebih efektif dibandingkan salep ekstrak teripang pasir dengan konsentrasi $60 \%$.

\section{Saran}

1. Teripang Pasir ( Holothuria scabra) dapat digunakan sebagai pengobatan alternatif untuk penyembuhan bengkak pada kaki dikalangan masyarakat

2. Perlu dilakukan penelitian lebih lanjut lagi mengenai isolasi senyawa aktif yang berkhasiat dalam teripang pasir ( Holothuria scabra).

\section{DAFTAR PUSTAKA}

Albuntana, A., Yasman dan Wardhana, W.,(2011), Uji Toksisitas Empat Jenis Teripang Suku Holothuriidae dari Pulau Penjaliran Timur, Kepulauan Seribu, Jakarta Menggunakan Brine Shrimp Lethality Test (BSLT), Jurnal Ilmu dan Teknologi Kelautan Tropis, 3(1):65-72 
Bordbar, S., Farooq Anwar, and Nazamid Saari. 2011. High-Value Components and Bioactives from Sea Cucumbers for Functional Foods-A Review. www.mdpi.com/journal/marinedrugs (4 April 2016)

Darsono, P. (2007). Teripang (Holothuridea) : Kekayaan Alam Dalam Keragaman Biota Laut. Oseana, Volume xxxii, Nomor $2: 1-10$.

Dinda Ayyu Hanjaya. 2013. UJI Aktivitas Ekstrak Teripang Bilalo (Actinopyga mauritiana (Quoy) Gaimard)) terhadap jamur Candida albicans. Medan: Universitas Sumatera Utara. (skripsi)

Drs. Tan Tjay, Drs Kirana Rahardja. (2007). Obat Obat penting edisi keenam. Jakarta : PT. Elex Media komputindo kelompok Kompas - Gramedia.

Erlina Rustamdkk.2007.Efek Antiinflamasi Ekstrak Etanol Kunyit (Curcuma domestica Val.) Fakultas Kedokteran Universitas Andalas. Jurnal Sains dan Teknologi Farmasi, Vol. 12, No. 2,2007, halaman 112-115

Hanifah, Nurul.2015. Efek Anti Inflamasi Kitosan Dari Cangkang Udang Pantai Trisik Pada Tikus Model Rheumatoid Arthriti. Fakultas Farmasi, Universitas Ahmad Dahlan. Jurnal sains dan Teknologi Farmasi, Vol. 5, No. 2, 2015 halaman 177-184

Hidayat, Ricky. 2010. Efek Analgesik Dan Anti-Inflamasi Jus Buah Nanas (Ananas comosus L. ) Pada Mencit Betina Galur Swiss. Yogyakarta : Fakultas FarmasiUniversitas Sanata Dharma. (Skripsi).

Indra Sri Wahyuni. (2012). Efek Antiradang Ekstrak Air Teripang Pasir (Holothuria scabra) Terhadap Tikus Jantan yang diinduksi Karagenin. Surakarta : Fakultas Farmasi Universitas Muhammadiyah Surakarta. (Skripsi).

Fatmawaty B; Rosdiana Natzir; M.Natsir Djide. (2009). Potensi formula gel teripang pasir (holothuria scabra) untuk pengobatan luka bakar. Makassar : Lembaga Penelitian dan Pengabdian Masyarakat (Lp2m) Universitas Hasanuddin

Kordi, M. Ghufron., (2010). Cara Gampang Membudidayakan Teripang.Yogyakarta : Lily Publisher.

Kustiariyah, (2007) Teripang Sebagai Sumber Pangan dan Bioaktif, Buletin Teknologi Hasil Perikanan, X No.1.http://journal.ipb.ac.id/index.php/jphpi/article/view/963(diakses tanggal 6 Februari 2016) 